\title{
FOLR2 Positive
}

National Cancer Institute

\section{Source}

National Cancer Institute. FOLR2 Positive. NCI Thesaurus. Code C142835.

An indication that folate receptor beta has been detected in a sample. 